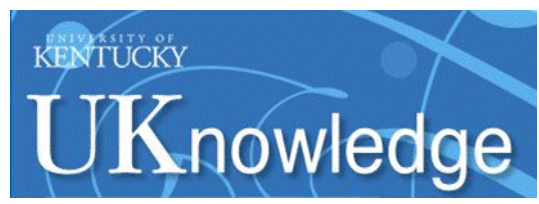

University of Kentucky

UKnowledge

$11-1998$

\title{
Fecal Bacteria Survival and Infiltration through a Shallow Agricultural Soil: Timing and Tillage Effects
}

\author{
C. S. Stoddard \\ University of Kentucky \\ Mark S. Coyne \\ University of Kentucky, mark.coyne@uky.edu \\ John H. Grove \\ University of Kentucky, jgrove@uky.edu
}

Follow this and additional works at: https://uknowledge.uky.edu/pss_facpub

Part of the Environmental Microbiology and Microbial Ecology Commons, and the Plant Sciences Commons

Right click to open a feedback form in a new tab to let us know how this document benefits you.

\section{Repository Citation}

Stoddard, C. S.; Coyne, Mark S.; and Grove, John H., "Fecal Bacteria Survival and Infiltration through a Shallow Agricultural Soil: Timing and Tillage Effects" (1998). Plant and Soil Sciences Faculty Publications. 9.

https://uknowledge.uky.edu/pss_facpub/9

This Article is brought to you for free and open access by the Plant and Soil Sciences at UKnowledge. It has been accepted for inclusion in Plant and Soil Sciences Faculty Publications by an authorized administrator of UKnowledge. For more information, please contact UKnowledge@lsv.uky.edu. 
Fecal Bacteria Survival and Infiltration through a Shallow Agricultural Soil: Timing and Tillage Effects

Digital Object Identifier (DOI)

http://dx.doi.org/10.2134/jeq1998.00472425002700060031x

Notes/Citation Information

Published in Journal of Environmental Quality, v. 27, no. 6, p. 1516-1523.

The copyright holder has granted the permission for posting the article here.

This article is available at UKnowledge: https://uknowledge.uky.edu/pss_facpub/9 


\title{
Fecal Bacteria Survival and Infiltration through a Shallow Agricultural Soil: Timing and Tillage Effects
}

\author{
C. S. Stoddard, M. S. Coyne, ${ }^{*}$ and J. H. Grove
}

\begin{abstract}
Human and livestock exposure to fecal pathogens via contaminated surface or groundwater is an important water quality concern for soils receiving animal wastes. The effects of manure application timing (spring or fall application) and soil management (no-tillage or conservation tillage) on fecal bacteria infiltration through shallow karst soils in central Kentucky (the Bluegrass region) have not been evaluated. We performed a field experiment to measure fecal coliforms and fecal streptococci in leachate from dairy manure-amended no-tillage and conservation tillage soils. Manure significantly increased fecal bacteria in leachate compared with unmanured treatments. After manure application, the leachate that collected in zero-tension lysimeters $90 \mathrm{~cm}$ below the soil surface contained up to $6 \times 10^{4}$ fecal coliforms $/ 100 \mathrm{~mL}$ and generally exceeded $3 \times 10^{3}$ fecal coliforms $/ 100 \mathrm{~mL}$. Neither the timing nor the tillage method significantly affected fecal coliform concentrations in leachate. Fecal bacteria in leachate declined to nondetectable levels within $60 \mathrm{~d}$ of manure application. In the well structured soil used in this experiment, fecal bacteria moved below the crop root zone whenever there was rainfall of sufficient duration or intensity to cause flow after manure application. Manure application to no-tillage soil in spring did not accelerate water contamination by fecal coliforms relative to fall manure applications. No-tillage did not accelerate water contamination by fecal coliforms relative to tilled soils. The potential for groundwater contamination depended on soil structure and water flow more than on fecal bacteria survival at the soil surface.
\end{abstract}

$\mathrm{O}$ $\mathrm{NE}$ of the main concerns with land-applying animal manure is that bacterial pathogens will reach groundwater. Considerable research has addressed the characteristics (Fontes et al., 1991) and modeling (Corap cioglu and Haridas, 1985; Peterson and Ward, 1989) of bacterial transport in homogenous (Gannon et al., 1991a,b), undisturbed (Smith et al., 1985), and model (Sharma and McInerney, 1994) soil systems. Soil tillage management also affects whether soil is a good or poor medium for bacterial filtration, but this has not been widely evaluated at the field scale. In shallow, welldrained, karst soils, which occur in central Kentucky (the Bluegrass region), no-tillage is practiced to control erosion, but the consequences of manure application to no-tillage soils, and its effect on groundwater, are undocumented.

Agronomic practices, such as manure application and no-tillage, influence soil structure and affect water movement. Well structured soils may have macropore flow, which allows water infiltration without appreciably wetting the soil mass (Thomas and Phillips, 1979). Solutes and bacteria can rapidly move from the soil surface to significant depths, followed by a slower moving front of displaced water. For example, Escherichia coli

Department of Agronomy, Univ. of Kentucky, Lexington, KY 405460091. Received 9 Dec. 1997. *Corresponding author (mscoyn00@ pop.uky.edu).

Published in J. Environ. Qual. 27:1516-1523 (1998).
(E. coli) move rapidly through well-structured soils with moderate to high water addition rates (Smith et al., 1985). Rahe et al. (1978) demonstrated that $E$. coli recovery in sampling wells distant from a point source of contamination could occur before $E$. coli recovery closer to that point source. Significant water quality degradation can occur soon after liquid manure application to tile-drained soils (Dean and Foran, 1992).

The effect of tillage (or lack thereof, i.e., no-tillage) on bacterial infiltration is poorly documented for field conditions. Evidence of microbial transport through well structured soils (Smith et al., 1985) and of no-tillage effects on soil structure and water transmission (Blevins et al., 1983) suggest that no-tillage would enhance bacterial movement through soil. Dean and Foran (1992) noted that fields tilled before manure application had insignificant microbial contamination in the drainage water. They suggested that shearing of macropores at the soil surface limited microbial transport.

The objectives of this field study were to evaluate fecal coliform and fecal streptococci transport through shallow no-tilled and conservation tilled soil amended with dairy manure in the fall and spring, and to assess the survival of these indicator bacteria in the manured soil.

\section{MATERIALS AND METHODS}

\section{Study Site and Experimental Design}

This experiment started in 1991 at the Kentucky Agricultural Experiment Station in Lexington to examine the response of continuous corn (Zea mays L.) and vadose zone water quality to dairy (Bos taurus) manure application, tillage, and fertilizer $\mathrm{N}$ rate. Only the water quality data with respect to fecal bacteria concentrations are reported here. The soil was a Maury silt loam (fine, mixed, mesic Typic Paleudalf), a well drained soil formed in the residuum of phosphatic Ordovician limestone. The site was in bluegrass and fescue sod (Poa pratensis L. and Festuca arundinacea L., respectively) for at least $10 \mathrm{yr}$ before initiating the experiment.

A typical pedon for the Maury series has weak to moderate granular structure in the Ap horizon (0-18 cm) (A.D. Karathanasis et al., 1993, unpublished data). The BA horizon (41-32 $\mathrm{cm}$ ) has weak medium subangular blocky structure. The Bt1 $(32-48 \mathrm{~cm})$ and $\mathrm{Bt} 2$ horizons $(48-63 \mathrm{~cm})$ exhibit moderate medium subangular blocky structure. The Bt3 horizon (63-102 $\mathrm{cm}$ ), which includes the depth to which lysimeters were installed, has moderate medium and coarse subangular blocky structure. Depth to bedrock ranges from as little as $152 \mathrm{~cm}$ to greater than $502 \mathrm{~cm}$. Maury soils at this site have permeability ranging from 5 to $15 \mathrm{~cm} / \mathrm{h}$ (Blevins et al., 1990).

The experimental design was a split-plot laid out in three randomized blocks. Treatment structure was a complete factorial with six tillage-manure timing treatments and $3 \mathrm{~N}$ rates as subplots. Main plots consisted of (i) no-tillage, no manure; (ii) no-tillage, fall manure; (iii) no-tillage, spring manure; (iv)

Abbreviations: CFU, colony forming units; GLM, general linear models; LSD, least significant difference. 
no-tillage, fall and spring manure; (v) conservation tillage (i.e., chisel/disk), no manure; and (vi) conservation tillage, spring manure. This report includes data collected in a 2-yr period from April 1993 to March 1995.

\section{Lysimeter Installation}

Twenty stainless steel, tension-free, pan lysimeters (Tyler and Thomas, 1977) were installed within the field experiment in April and May 1993 to observe treatment effects on groundwater quality. The lysimeters measured 0.61 by $0.91 \mathrm{~m}$ in area, and were $25.4 \mathrm{~cm}$ at their deepest point. The top of each lysimeter was covered by stainless steel expanded metal and two sheets of wicking nylon cloth to exclude sediment and to maintain hydraulic contact with the overlying soil. Each lysimeter had a volume of approximately $85 \mathrm{~L}(15 \mathrm{~cm}$ rain capacity). Lysimeters were installed in two replicates of subplots (those amended with 0 and $168 \mathrm{~kg} \mathrm{~N} / \mathrm{ha}$ ) within the main plot treatments (tillage-manure timing). Sixteen of the 20 pans were used to test tillage and presence or absence of spring manure and 8 of the 20 pans were used to test manure timing effects (data from some sets of pans were applicable to more than one treatment effect).

The lysimeters were placed at a $90-\mathrm{cm}$ depth, midway between the two center corn rows in each plot, and $1.8 \mathrm{~m}$ from the end of selected plots (Fig. 1). To minimize soil disturbance, a trench was dug adjacent to selected plots. Soil from the trench was separated into subsoil and topsoil for backfilling. A lysimeter was installed under each selected plot by digging a slot in the trench wall so that the front of the lysimeter was flush with the trench wall. The top of each slot was prepared to facilitate uniform contact with the surface of the lysimeter. The soil was then packed tightly around the lysimeter to ensure good contact between it and the soil, and to prevent movement of the lysimeter or overlying soil. Once lysimeter installation was complete, a PVC access tube was attached with a liquid sealant to an elbow joint on the lysimeter, and the trench was backfilled according to soil layer. The elbow joint prevented channeling of leachate around the PVC pipe from directly entering the lysimeters.

\section{Field Operations}

Dairy manure was surface-applied with a commercial spreader to appropriate main plots before planting in late April to early May for the spring manure treatments, and postharvest in early to mid-November for the fall manure treatments. The manure was 20 to $35 \%$ solids and exposure to sunlight before application was minimal. The seasonal delivery rates $(\mathrm{Mg} /$ ha dry manure) were 10.3 in spring $1993,8.6$ in fall 1993, 11.6 in spring 1994, and 15.9 in fall 1994.

Immediately following spring manure application, tilled treatments were chisel plowed to a depth of 20 to $25 \mathrm{~cm}$ and disked twice. Chiseling was performed using twisted $10-\mathrm{cm}$ shanks on $30-\mathrm{cm}$ centers. No cultivation was performed on the no-tillage plots, including those that received manure. Corn cultivar Pioneer '3279' was planted on 21 May 1993 and 10 May 1994 at 57000 seeds/ha. Contact and preemergence herbicide applications resulted in excellent weed control. Nitrogen fertilizer was top-dressed 5 to $6 \mathrm{wk}$ after planting. Winter rye (Secale cereale $\mathbf{L}$.) was drilled in $17.8 \mathrm{~cm}$ rows on all plots after harvest, but before fall manure application.

\section{Leachate Sampling}

Leachate sampling began on 14 June 1993 (approximately 1 mo after installation of all pans was completed) before fall manure addition, and continued through 15 Mar. 1995. Leachate was collected and volumes measured 24 to $48 \mathrm{~h}$ after each rain of sufficient intensity and/or duration to cause drainage.

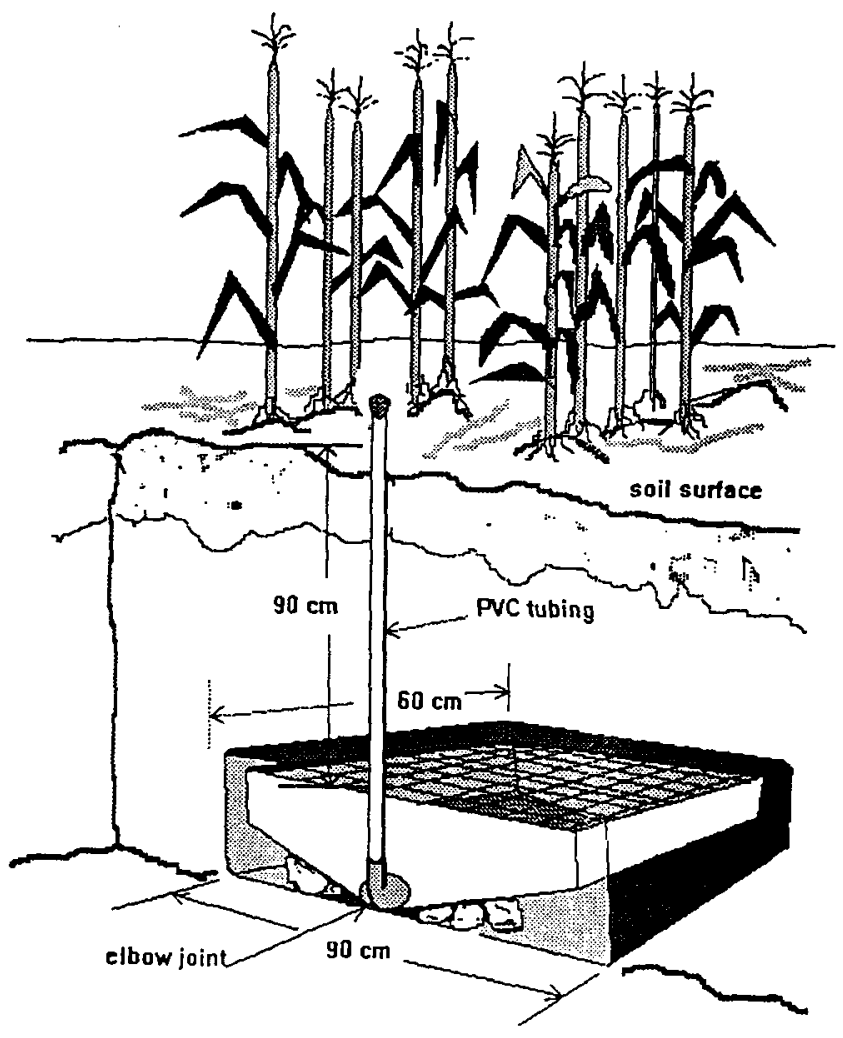

Fig. 1. Illustration of lysimeters installed $90 \mathrm{~cm}$ below the soil surface. Soil above the lysimeter was not disturbed.

Samples were collected using a hand-held plastic rotary pump. The pump, tubing, and sample container were rinsed with deionized water before sampling. The first $200 \mathrm{~mL}$ of leachate from a lysimeter was used to rinse the pump, tubing, and sample container and discarded. A $500-\mathrm{mL}$ aliquot (or the remainder of the leachate in the lysimeter) was then collected for analysis. Approximately $120 \mathrm{~mL}$ was poured into an autoclaved plastic bottle for bacterial analysis. The lysimeter was then pumped dry and the volume recorded. This procedure was repeated for each lysimeter. Leachate samples were refrigerated at $4^{\circ} \mathrm{C}$ and analyzed for fecal coliforms and fecal streptococci within $2 \mathrm{~d}$, usually within $24 \mathrm{~h}$.

\section{Fecal Bacteria Survival in Manured Soil}

Three survival studies were performed, the first in May 1993, the second in November 1993, and the third in April 1994. A few samples were also taken following manure application in the fall of 1994 . Immediately after the May 1993 manure application, nine soil cores $(0-15 \mathrm{~cm}$ depth) were randomly taken along the length of each main plot with a hand-held soil probe, alternating between the rows of stalks, composited, placed in sterile plastic bags, and refrigerated at $4^{\circ} \mathrm{C}$. Only no-tillage plots and plots that received spring manure were sampled. Three unmanured strips were also sampled as controls and as baseline measurements of fecal coliforms and fecal streptococci in soil. Soil samples were collected using this protocol every week for $5 \mathrm{wk}$, then on a monthly basis until bacteria counts declined to levels comparable to those of the unmanured controls. Immediately after the November 1993 manure application, samples were taken from no-tillage plots that received manure. Sampling frequency was every $2 \mathrm{~d}$ for $2 \mathrm{wk}$, then at weekly intervals for $4 \mathrm{wk}$, and on a monthly basis thereafter. Background bacterial concentrations were determined in plots $1 \mathrm{~d}$ before manure application.

The main goal of the survival study performed in spring 1994 was to observe the effects of tillage (no-tillage vs. conservation 
tillage) on bacterial mortality after spring manure application. Surface soil samples were taken every 2 wk, as previously described, on appropriate main plots immediately following manure and tillage operations.

\section{Fecal Bacteria Analyses}

Within $24 \mathrm{~h}$ of soil sample collection, fecal coliforms in soil were quantified by membrane filtration and most probable number methods, while fecal streptococci were quantified by membrane filtration methods alone (APHA, 1992). Ten grams of hand sieved, moist soil were added to $90 \mathrm{~mL}$ of sterile $0.05 \% \mathrm{NaCl} / \mathrm{phosphate}$ buffer and agitated on a mechanical shaker for $20 \mathrm{~min}$. These solutions were serially diluted $10-$ fold. Soil moisture was measured on all soil samples and results are expressed as colony forming units (CFU) on an oven-dry soil weight basis.

Presterilized, gridded, $0.45-\mu \mathrm{m}$ membrane filters were used for membrane filtration. Duplicate filters were inoculated with $10 \mathrm{~mL}$ each of sample from an appropriate dilution (one that would yield between 20 and 200 well-isolated colonies) and placed on Difco mFC agar (Difco Co., Detroit, MI) for fecal coliforms, and Difco KFS agar for fecal streptococci. mFC agar plates were incubated at $44.5^{\circ} \mathrm{C}$ for $24 \mathrm{~h}$ and KFS plates were incubated at $35^{\circ} \mathrm{C}$ for $48 \mathrm{~h}$. Only those glistening colonies that were blue to dark blue on $\mathrm{mFC}$ plates were counted as fecal coliforms. All red to rust-colored colonies that could be seen without magnification on KFS plates were counted as fecal streptococci.

The MPN method was performed using Difco EC-MUG (E. coli 4 -methylumbelliferyl $\beta$-D-glucuronide) broth with 5 tubes/dilution. One $\mathrm{mL}$ of sample was added to each tube, incubated at $44.5^{\circ} \mathrm{C}$ for $48 \mathrm{~h}$, then exposed to long wave UV light $(366 \eta \mathrm{m})$ for enumeration. Fluorescence indicated a positive (presence of $\beta$-glucuronidase positive $E$. coli) MUG reaction. The MPN of fecal coliforms in soil was calculated according to published tables in Alexander (1982) for use with 10 -fold serial dilutions and 5 tubes/dilution.

Fecal coliforms were enumerated in leachate samples from the lysimeters to assess the extent of fecal coliform infiltration through the Maury soil (fecal streptococci data were incomplete and they are not reported in this study). Leachate sample data correspond to manure applications on 12 May 1993, 24 Nov. 1993, 20 Apr. 1994, and 30 Nov. 1994. Leachate samples were refrigerated at $4^{\circ} \mathrm{C}$ until enumeration. Fecal coliform analyses were performed using the membrane filtration technique previously described.

\section{Statistical Analyses}

Soil samples were analyzed for bacterial mortality studies after assuming logarithmic first-order exponential decay (Eq. [1]):

$$
M_{t}=M_{0} e^{-k t}
$$

where $M_{t}=$ the microbial concentration at time $t, M_{0}==$ the initial microbial concentration, $k=$ the first order rate coefficient for the net mortality rate for organisms/day, and $t=$ the time in days. Regression analyses were performed on the average plate counts of fecal coliforms and fecal streptococci for each field replication after any regrowth had occurred. The data from each season were modeled, assuming an exponential death rate as given in Eq. [1] for the entire sampling period within each season (147 d for spring and $112 \mathrm{~d}$ for fall in 1993; $80 \mathrm{~d}$ in spring 1994). The average daily air temperature during the study period is shown in Fig. 2.

The leachate data were analyzed by subdividing the year into eight seasonal periods as described in Table 1. Grouped data facilitated analysis and reduced the influence of individual events on variation. Mean microbial counts for fecal coliforms in leachate samples were analyzed, by period, after log transforming the original data to stabilize the variances (no flow weighted averaging was performed). A normal distribution of the transformed data was assumed. Statistical analyses were performed using the Statistical Analysis System v. 6.0 (SAS Inst., 1989). The general linear models (GLM) procedure was used for the analysis of variance. Separate statistical analyses were performed on the lysimeter data to determine the main effects of spring manure application and tillage (16 pans) and the main effects of manure application timing (eight pans). The manure timing analysis was performed as a $2 \times 2$ factorial arrangement (presence vs. absence of manure by fall vs. spring application). Means separation among treatments was determined by least significant difference (LSD). Though a significance level of $\alpha=0.05$ is traditional, consideration of the relative risk of Type I or Type III decision errors, vs. Type II decision error, led us to choose a significance level of $\alpha=$ 0.25 . For a thorough discussion of the consequence of significance level selection on risk assessment and management decisions, see Carmer and Walker (1988).

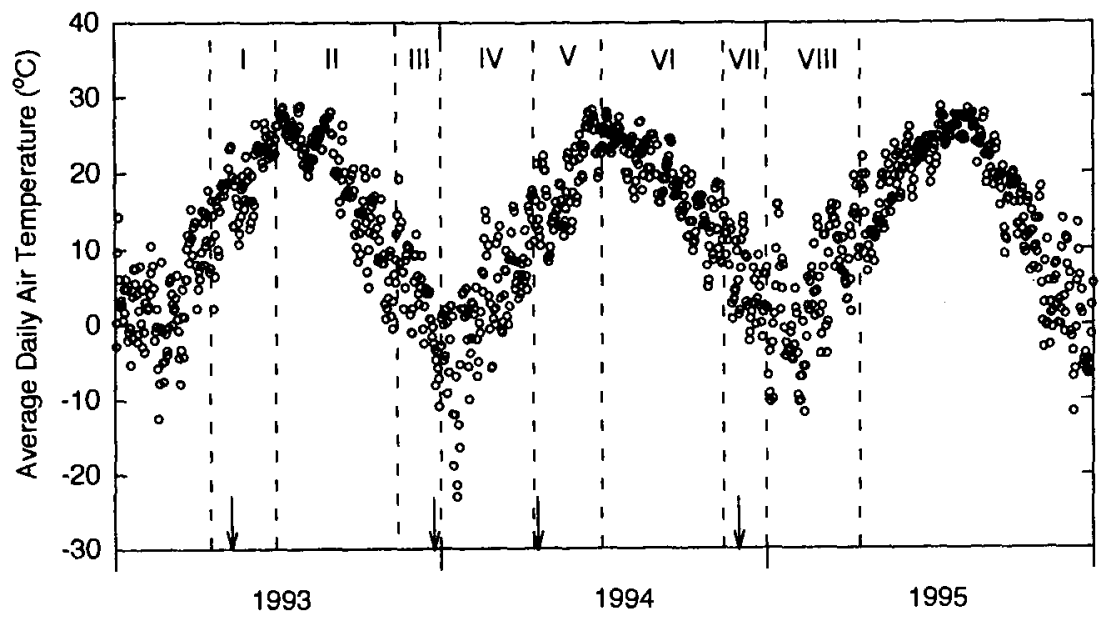

Fig. 2. Average daily air temperatures at the experiment site for the 3-yr period encompassing the study. Arrows indicate dates of manure application corresponding to 12 May 1993, 24 Nov. 1993, 20 Apr. 1994, and 30 Nov. 1994. The relevant periods into which the data was organized for statistical analysis are denoted by the roman numerals between the delineating lines. The corresponding dates for each period are given in Table 1. 
Table 1. Sample periods for leachate analysis and precipitation measures.

\begin{tabular}{|c|c|c|c|c|c|c|}
\hline Period & $\begin{array}{c}\text { Inclusive } \\
\text { dates }\end{array}$ & $\begin{array}{l}\text { Rain } † \\
\text { events }\end{array}$ & $\begin{array}{c}\text { Sampling } \\
\text { events }\end{array}$ & $\underset{\text { precipitation }}{\text { Total }}$ & $\begin{array}{l}\text { Maximum } \\
\text { rain event }\end{array}$ & $\begin{array}{l}\text { Average } \\
\text { rain event }\end{array}$ \\
\hline Spring 1993 & $\begin{array}{l}15 \text { April- } \\
30 \text { June }\end{array}$ & 15 & 4 & 26.9 & $\begin{array}{c}-\mathrm{cm} \mathrm{H}_{2} \mathrm{O} \\
6.0\end{array}$ & $2.0 \pm 1.7 \div$ \\
\hline Summer 1993 & $\begin{array}{l}1 \text { July- } \\
14 \text { November }\end{array}$ & 25 & 4 & 46.7 & 8.7 & $1.7 \pm 2.1$ \\
\hline Fall 1993 & $\begin{array}{l}15 \text { November- } \\
31 \text { December }\end{array}$ & 10 & 3 & 14.4 & 8.8 & $2.2 \pm 2.7$ \\
\hline Winter 1994 & $\begin{array}{l}1 \text { January- } \\
14 \text { April }\end{array}$ & 20 & 6 & 42.7 & 6.3 & $2.0 \pm 2.1$ \\
\hline Spring 1994 & $\begin{array}{l}15 \text { April- } \\
30 \text { June }\end{array}$ & 16 & 4 & 20.9 & 5.3 & $1.9 \pm 1.9$ \\
\hline Summer 1994 & $\begin{array}{l}1 \text { July- } \\
14 \text { November }\end{array}$ & 21 & 3 & 34.3 & 6.8 & $1.5 \pm 1.5$ \\
\hline Fall 1994 & $\begin{array}{l}15 \text { November- } \\
31 \text { December }\end{array}$ & 8 & 3 & 12.6 & 3.6 & $1.8 \pm 1.5$ \\
\hline Winter 1995 & $\begin{array}{l}1 \text { January- } \\
14 \text { April }\end{array}$ & 21 & 5 & 25.5 & 5.7 & $1.1 \pm 1.6$ \\
\hline
\end{tabular}

$\dagger$ A rain event was considered to be all consecutive days in which measurable precipitation occurred $(>0.03 \mathrm{~cm})$.

$\$$ Mean \pm 1 standard deviation.

\section{RESULTS}

\section{Fecal Bacteria Survival in Soil}

Most probable number is the preferred method to enumerate fecal coliforms in soil because soil particulates and debris tend to clog and obscure filters and make enumeration difficult when the membrane filtration method is used (Turco, 1994). Nevertheless, we used membrane filtration to enumerate fecal coliforms in our soil samples because sufficient dilution occurred during dilution procedures to minimize filter clogging, and because regression analysis performed on the logtransformed soil and water data showed a significant $(p \leq 0.01)$ linear correlation $(r=0.91$ and 0.95 , respectively) between fecal coliform enumeration by membrane filtration or MPN (Fig. 3). Therefore, fecal coliform data are presented as colony forming units as measured by membrane filtration. This allowed a direct comparison to fecal streptococci data, which were only obtained by membrane filtration. Even though extraction efficiency was undoubtedly $<100 \%$, all samples were treated identically, so the test of treatment effects on fecal bacteria survival should not have been compromised.

The mean fecal coliform and fecal streptococci numbers in manured treatments sampled immediately before and after manure application are presented in Table 2. Manure was unevenly distributed within main plots; consequently, microbial concentrations were extremely variable. The mean fecal coliform and fecal streptococci concentrations in the control samples before manure application (approximately $50 \mathrm{CFU} / \mathrm{g}$ ) were used to determine when manured treatments reached background levels. Fecal coliforms and fecal streptococci declined to background levels in about 6 mo after spring manure applications and within 2 mo after fall manure applications (Fig. 4).

Fecal coliform mortality was significantly affected by season. Fecal coliform mortality was delayed in spring 1993 but began immediately after manure application in fall 1993. The mortality rate constant $(k)$ for fecal coliforms after the fall application was significantly greater than after spring application $(p \leq 0.05)$ (Table 3 ). In contrast, the fecal streptococci mortality rate was significantly greater in spring than in fall $(p \leq 0.05)$ (Table 3).

No differences due to tillage were found in the mortality rate constants after the 1994 spring manure applica-
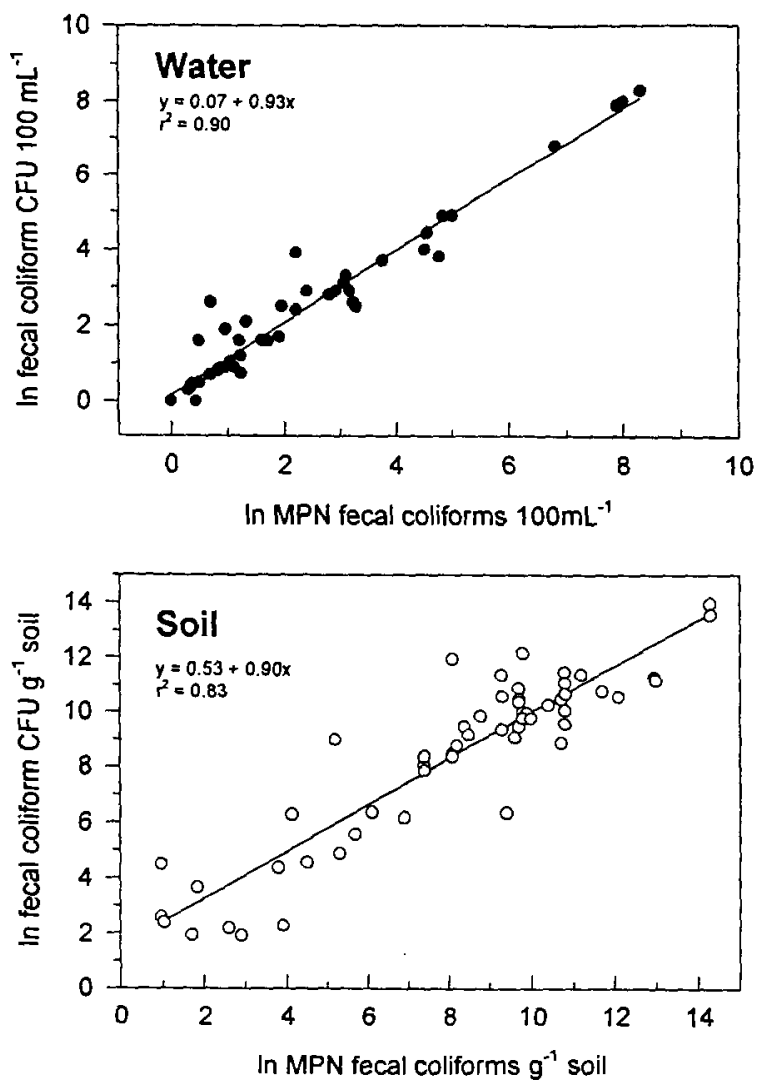

Fig. 3. Regression analysis of the correlation between fecal coliforms in soil and water samples enumerated by either membrane filtration or most probable number (MPN) techniques. 
Table 2. Initial fecal coliform (FC) and fecal streptococci (FS) concentrations in manured and unmanured soils.

\begin{tabular}{|c|c|c|c|c|}
\hline \multirow{2}{*}{$\begin{array}{l}\text { Application } \\
\text { date }\end{array}$} & \multicolumn{2}{|c|}{ Unmanured $\dagger$} & \multicolumn{2}{|c|}{ Manured } \\
\hline & FC & FS & FC & FS \\
\hline & & _____ colony of & dry soil & \\
\hline $\begin{array}{l}10 \text { May } 1993 \\
24 \text { Nov. } 1993 \\
20 \text { April } 1994\end{array}$ & $\begin{array}{l}7 \times 10^{1} \pm 5 \times 10^{1} \\
1 \times 10^{1} \pm 7 \times 10^{0} \\
3 \times 10^{1} \pm 4 \times 10^{1}\end{array}$ & $\begin{array}{c}1 \times 10^{2} \pm 1 \times 10^{2} \\
2 \times 10^{2} \pm 1 \times 10^{2} \\
\text { nd } \$\end{array}$ & $\begin{array}{l}5 \times 10^{5} \pm 4 \times 10^{5} \\
7 \times 10^{5} \pm 2 \times 10^{5} \\
7 \times 10^{5} \pm 2 \times 10^{5}\end{array}$ & $\begin{array}{l}7 \times 10^{5} \pm 4 \times 10^{5} \\
9 \times 10^{5} \pm 5 \times 10^{5} \\
1 \times 10^{5} \pm 3 \times 10^{5}\end{array}$ \\
\hline
\end{tabular}

$\dagger$ Unmanured treatments were sampled $1 \mathrm{~d}$ before manure application.

\pm 1 Standard error of the mean $(n=3)$.

$\S$ No data.

tion (Table 3), but tillage affected the total fecal bacteria enumerated at each sampling event. Conservation tilled soil had consistently fewer fecal coliforms and fecal streptococci/gram dry soil than did no-tillage soil, presumably because greater dilution of fecal bacteria occurred within the tilled soil (data not shown).

\section{Fecal Coliform Transport}

Fecal coliforms moved to at least $90 \mathrm{~cm}$ (the depth of the lysimeters) with the first rain sufficient to cause leaching after manure application. Of the 136 rain events that occurred during the study, $24 \%$ produced enough leachate to sample (Table 1). Modest rain could cause leaching. The first event after the three initial manure applications averaged only $1.4 \mathrm{~cm}(3.3 \mathrm{~cm}$ for the last manure application).

A comparison of the fecal coliform leachate concentrations in spring manure treatments and unmanured controls is presented in Table 4 (fecal streptococci data are not shown due to missing data). Contamination of leachate in the controls and fall-only manure treatments occurred after the spring application. This contamination was most likely due to the manure application method, since the commercial spreader used in this experiment had some over spray. Manure application significantly increased fecal coliform concentrations in leachate compared to unmanured controls $(p \leq 0.25)$ in spring 1993 and 1994, and winter 1995.

In the first lysimeter sample after spring manureapplication, fecal coliform concentrations in no-tillage

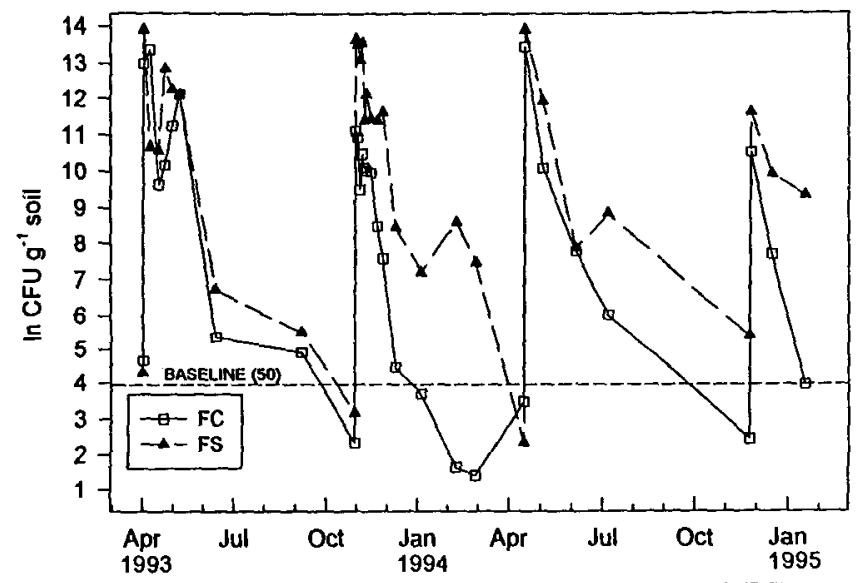

Fig. 4. The mean fecal coliform (FC) and fecal streptococei (FS) concentrations/gram of dry soil as affected by manure application during the study period. Manure was applied in April and November of each year. Baseline is the mean fecal coliform and fecal streptococci concentration in unmanured plots. leachate were as great or greater than those found in leachate from tilled soil (Fig. 5). Although conservation tillage treatments tended to have higher mean fecal coliform concentrations throughout the experiment, this trend was not consistent. Tillage significantly affected fecal coliform leachate concentrations only in the spring and fall of 1993, and spring 1994 ( $p \leq 0.25$ ) (Table 4). After the spring 1993 manure application, no-tillage had significantly higher fecal coliform concentrations than conservation tillage treatments $(p \leq 0.25)$. This result was reversed after the spring 1994 manure application. So, no conclusions can be drawn.

Average fecal coliform concentrations exceeding $60000 \mathrm{CFU} / 100 \mathrm{~mL}$ were measured following manure applications in spring and fall of 1994 (Fig. 6). The heaviest manure applications were also made during these periods. Fecal coliform concentrations in leachate from manured plots declined to nondetectable levels within $60 \mathrm{~d}$, and thereafter were not significantly different from unmanured treatments until the next manure application. Fecal coliform concentrations fluctuated frequently, however, often increasing again after the initial drop in concentration (Fig. 6) but not to levels exceeding $200 \mathrm{CFU} / 100 \mathrm{~mL}$.

The main effect of manure timing on fecal coliform concentrations was usually significant $(p \leq 0.25)$ in the period when manure was applied (i.e., spring and fall of 1993 and 1994) (Table 4). Thus, the treatment receiving both fall and spring manure applications usually had the highest mean fecal coliform concentrations in leachate samples throughout the experiment, ranging from nondetectable levels to $665 \mathrm{CFU} / \mathrm{mL}$ (Table 4).

Table 3. First-order mortality rates $(k)$ and half-lives $\left(t_{12}\right)$ of fecal coliforms (FC) and fecal streptococci (FS) after manure application.

\begin{tabular}{llllll}
\hline Period & Tillage $\dagger$ & Organism & $r^{2}$ & $\begin{array}{c}k \neq \\
\text { (ln CFU/d) }\end{array}$ & $t_{12} \S$ \\
\hline 1993 & & & & & \\
$\quad$ Spring & NT & FC & $\mathbf{0 . 7 1}$ & $\mathbf{0 . 0 9 b}$ & $\mathbf{7 . 7}$ \\
Fall & NT & FC & $\mathbf{0 . 8 8}$ & $\mathbf{0 . 1 2 a}$ & $\mathbf{5 . 8}$ \\
Spring & NT & FS & $\mathbf{0 . 5 5}$ & $\mathbf{0 . 0 8 a}$ & $\mathbf{8 . 7}$ \\
Fall & NT & FS & $\mathbf{0 . 7 5}$ & $\mathbf{0 . 0 5 b}$ & 13.9 \\
1994 & & & & & \\
Spring & NT & FC & $\mathbf{0 . 7 2}$ & $\mathbf{0 . 1 0 a}$ & 6.9 \\
Spring & CD & FC & $\mathbf{0 . 7 6}$ & $\mathbf{0 . 1 0 a}$ & $\mathbf{6 . 9}$ \\
Spring & NT & FS & $\mathbf{0 . 7 0}$ & $\mathbf{0 . 0 9 a}$ & $\mathbf{7 . 7}$ \\
Spring & CD & FS & $\mathbf{0 . 6 5}$ & $\mathbf{0 . 0 8 a}$ & $\mathbf{8 . 7}$ \\
\hline
\end{tabular}

$+\mathrm{NT}=$ no-tillage, $\mathbf{C D}=$ chisel/disk.

\# Estimated die-off coefficient/day assuming logarithmic first-order dieoff kinetics. Values within the same organism class with the same letter are not significantly different $(p<0.05)$.

§ Days needed to reduce fecal bacteria populations by $\mathbf{5 0} \%$. 
Table 4. Average fecal coliform concentrations in lysimeter pans as affected by manure and tillage for the eight periods of the study (April 1993-April 1995).

\begin{tabular}{|c|c|c|c|c|c|c|c|c|c|}
\hline \multirow{2}{*}{\multicolumn{2}{|c|}{ Treatment }} & \multicolumn{8}{|c|}{ Sample period } \\
\hline & & \multirow{2}{*}{$\begin{array}{c}\text { Spring } \\
1993\end{array}$} & \multirow{2}{*}{$\begin{array}{c}\text { Summer } \\
1993\end{array}$} & \multirow{2}{*}{$\begin{array}{r}\text { Fall } \\
1993\end{array}$} & \multirow{2}{*}{$\begin{array}{c}\text { Winter } \\
1994\end{array}$} & \multirow{2}{*}{$\begin{array}{c}\text { Spring } \\
1994\end{array}$} & \multirow{2}{*}{$\underset{1994}{\text { Summer }}$} & \multirow{2}{*}{$\begin{array}{c}\text { Fall } \\
1994\end{array}$} & \multirow{2}{*}{$\begin{array}{c}\text { Winter } \\
1995\end{array}$} \\
\hline Manure $\dagger$ & Tillage $\ddagger$ & & & & & & & & \\
\hline & & & & Main & f presen & nce of & 1anure & & \\
\hline \multirow{6}{*}{$\begin{array}{l}\mathbf{N} \\
\mathbf{S}\end{array}$} & & $\mathbf{1 . 3 b}$ & $1.2 \mathbf{a}$ & 1.1a & $0.07 a$ & $3.7 \mathrm{~b}$ & $\overline{1.7} \mathbf{a}$ & $0.7 \mathbf{a}$ & $0.1 \mathbf{b}$ \\
\hline & & $2.9 \mathrm{a}$ & $1.7 \mathbf{a}$ & $1.8 \mathbf{a}$ & $0.10 \mathrm{a}$ & $5.2 \mathrm{a}$ & $1.2 a$ & $0.5 a$ & $0.4 \mathrm{a}$ \\
\hline & & \multicolumn{8}{|c|}{ Main effect of tillage } \\
\hline & CD & $\mathbf{1 . 8 b}$ & $1.7 \mathbf{a}$ & $1.9 \mathrm{a}$ & $\overline{0.10 a}$ & $4.7 \mathrm{a}$ & $\mathbf{1 . 3 a}$ & $0.7 \mathbf{a}$ & $0.2 \mathrm{a}$ \\
\hline & $\mathbf{N T}$ & $2.9 \mathrm{a}$ & $1.2 \mathrm{a}$ & $1.0 \mathrm{~b}$ & $0.07 a$ & $\mathbf{4 . 3 b}$ & $\mathbf{1 . 5 a}$ & $\mathbf{0 . 5 a}$ & $0.4 \mathrm{a}$ \\
\hline & & \multicolumn{8}{|c|}{ Main effect of manure timing } \\
\hline $\mathbf{N}$ & NT & 3.1 & 1.9 & 1.0 & 0.3 & 4.7 & 2.2 & 0.7 & 0.4 \\
\hline $\mathbf{S}$ & NT & 2.0 & 1.9 & nd & nd & 5.3 & 1.0 & nd & 0.7 \\
\hline $\mathbf{F}$ & NT & 2.8 & 2.7 & 4.6 & 0.7 & 5.1 & 1.4 & 5.5 & 0.6 \\
\hline $\mathbf{F}+\mathbf{S}$ & NT & 4.0 & 3.2 & 3.8 & 0.3 & 7.7 & 0.8 & 6.5 & 1.3 \\
\hline LSD (0.25) & & 1.2 & 1.3 & 1.5 & 0.4 & 0.9 & 1.6 & 0.8 & 0.4 \\
\hline
\end{tabular}

$\dagger \mathbf{N}=$ none, $\mathbf{S}=$ spring, $\mathbf{F}=$ fall, and $\mathbf{F}+\mathbf{S}=$ fall and spring manure application.

$\ddagger \mathrm{CD}=$ chisel/disk, $\mathrm{NT}=$ no-tillage.

$\S$ Mean of the natural log of fecal coliform colony forming units/100 mL leachate. Means within a main effect and a sampling period, with the same letter, are not significantly different $(p>0.25)$.

II Not detectable.

\section{DISCUSSION}

\section{Methodological Considerations}

Leachate collection was performed without surface sterilizing the sampling equipment between lysimeters, so cross contamination between lysimeters was a concern. However, considerable rinsing of the sample equipment with distilled water occurred between samples, and the sampling equipment was also rinsed with leachate from each lysimeter. Since the approved method for minimizing cross contamination in the membrane filtration method is simply to rinse each funnel unit thoroughly with distilled water (APHA, 1992), the field protocol was judged to be sufficiently rigorous to negate cross contamination between lysimeters. There was no evidence that cross contamination occurred in our membrane filtration results.

The holding time (maximum of $2 \mathrm{~d}$ ) of leachate samples was longer than prescribed by standard methods for fecal coliform analysis in water (APHA, 1992). The principle concern is that mortality of fecal coliforms during storage would cause the potential for water contamination to be underestimated, which has serious reg-

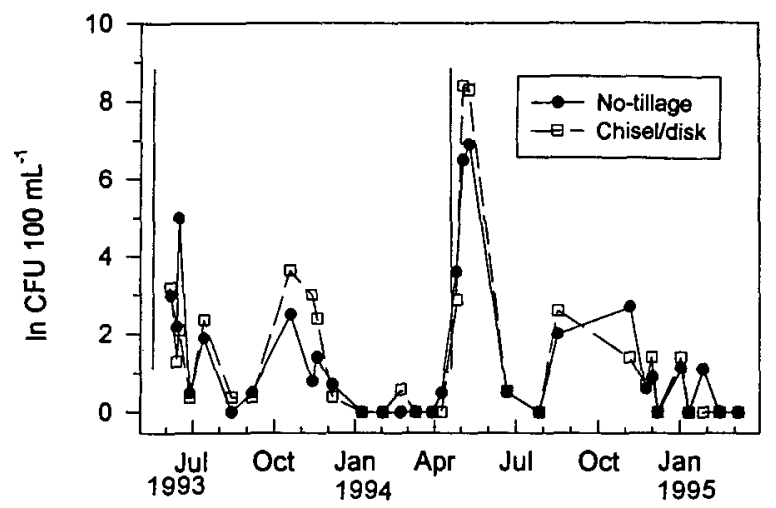

Fig. 5. Average fecal coliform (FC) concentration in leachate samples as affected by tillage during the study. Vertical lines indicate when manure was applied. ulatory impacts for drinking and recreational water. Our study, however, was not designed to generate data applicable to regulatory standards for water quality analysis; it was constrained by its need to adequately compare treatment effects. Consequently, we ensured that holding times were identical for all samples collected on the

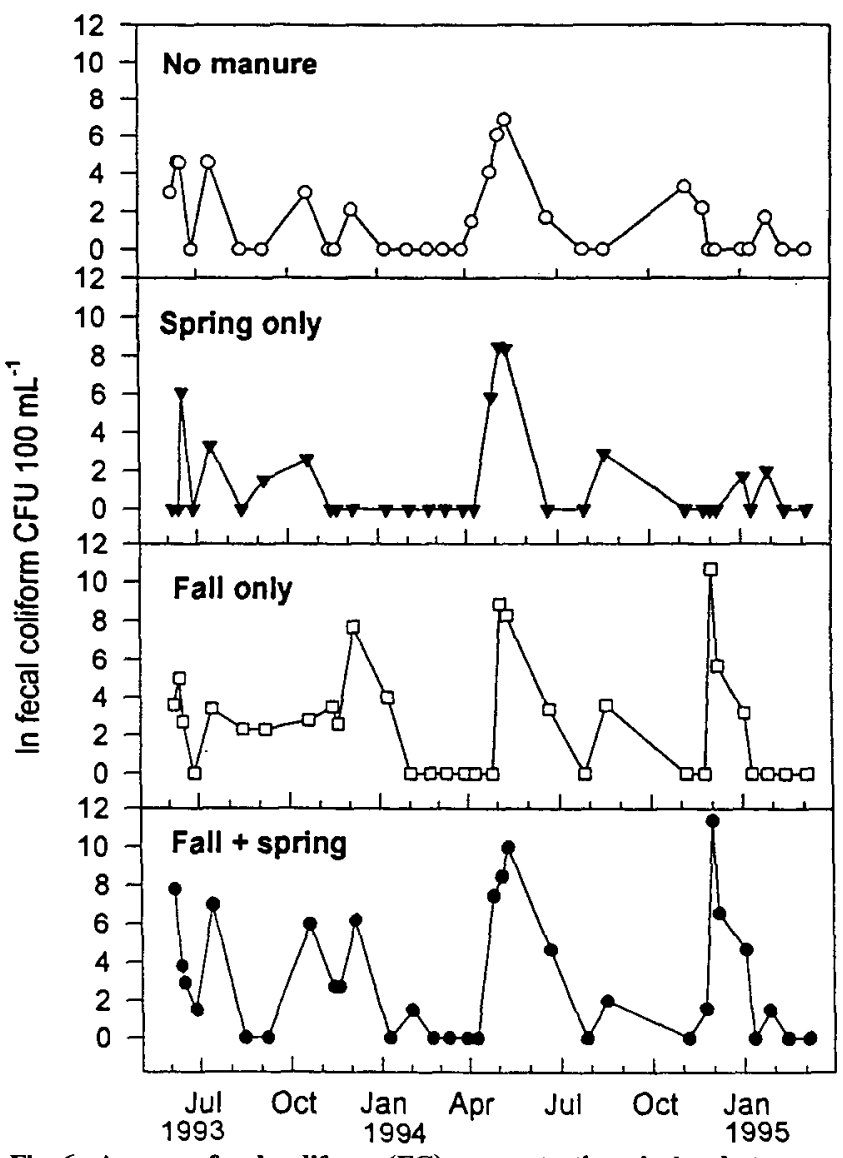

Fig. 6. Average fecal coliform (FC) concentrations in leachate samples as affected by manure application. Manure was applied in April and November of each year. 
same date rather than that they were all analyzed within $24 \mathrm{~h}$.

We did not feel constrained to process our samples for analysis within $24 \mathrm{~h}$ because Howell et al. (1996) demonstrated that fecal coliforms in cattle manure resuspended in water samples at $4^{\circ} \mathrm{C}$ (the holding temperature for our study) had a half-life of $15.6 \mathrm{~d}$. Consequently, we assumed that the potential mortality during a maximum 2-d holding period would not have affected the treatment comparisons in our study.

\section{Fecal Bacteria Survival in Soil}

Fecal bacteria numbers in soil usually decline to preapplication levels in 2 to 3 mo depending on soil temperature and potential exposure to desiccation and ultra violet light (Elliot and Ellis, 1977). Modeling fecal bacteria mortality within the surface $15 \mathrm{~cm}$ of no-tillage soil by first-order exponential decay was adequate to assess their decline in our study, but was complicated by a delay in the initial decline of the fecal bacteria, and their occasional regrowth. Moist conditions, mild temperatures, and manure crusting all contribute to fecal bacteria regrowth (Crane et al., 1980). Our enumeration procedures also quantified only culturable cells. We assume that injured/viable but nonculturable cells were present, but that their mortality rates were similar to that of the viable cells. Davies et al. (1995) showed that the proportion of culturable to viable but nonculturable $E$. coli in freshwater sediments was constant. Thus, we have probably underestimated the total fecal bacteria numbers at each sample period in soil and water, but reasonably reflected how those bacteria behave in terms of survival and transport in manure-amended fields relative to the treatments that we imposed.

Mixing soil and manure, in addition to diluting fecal bacteria, often increases fecal bacteria mortality rates (Reddy et al., 1981). Alternatively, manure may form crusts in no-tillage treatments, and fecal bacteria may persist within the crusted manure until their release by rainfall because of decreased interaction with the soil and atmosphere (Thelin and Gifford, 1983). However, the mortality rates for the 1994 manure application showed almost no difference between incorporated and unincorporated manure. Crust formation was either not great enough to enhance bacterial survival (for example, provide protection from desiccation and ultra violet light), or tillage operations were insufficient to cause greater soil-manure contact in conservation tillage treatments and increase the mortality rate for these bacteria.

The fecal streptococci enumerated in this study did not necessarily originate from the dairy manure, which complicated analysis of their mortality. Many fecal streptococci are indigenous soil residents and the heterogeneity of fecal streptococci in manure and soil may have affected the mortality rates we observed. Fecal streptococci regrowth in these samples may simply be a response of indigenous fecal streptococci to additional nutrients supplied by manure.

The most rapid mortality of fecal coliforms occurred after the fall manure application. This was most likely due to freezing conditions, which are usually lethal to fecal bacteria, especially when several freeze-thaw cycles occur in conjunction with high $(>35 \%)$ soil moisture levels (Kibbey et al., 1978). Night temperatures following the fall 1993 manure application were below freezing within the first week, and by the end of December the temperature had dropped as low as $-20^{\circ} \mathrm{C}$.

\section{Fecal Bacteria Transport}

Fecal coliform concentrations in leachate samples and the potential for groundwater contamination from surface-applied manure were similar, regardless of when manure was applied. Midsummer or midwinter applications might have given dramatically different results because of greater climatic stress (e.g., desiccation or freezing). The average rain events in summer periods, for example, were among the lowest we observed in the study. From an agronomic point of view, however, manure application during midsummer or midwinter would be neither common nor recommended practice.

While the observed mortality rates in this study were greater in fall than spring, this difference was not large enough to attenuate leachate concentrations after a late fall manure application. Rather, bacterial concentrations in leachate samples were similar regardless of when manure was applied (Fig. 4). Additionally, mortality rates appeared to have little effect on the time required for leachate samples to drop to preapplication levels. This suggests that the mortality rate of fecal coliforms within 2 mo after a manure application has little bearing on the potential for bacterial groundwater contamination. Instead, the potential for groundwater contamination depended more on soil structure and water flow.

The elevated fecal coliform concentrations that appeared in leachate with the first rain sufficient to cause drainage after manure application were consistent with other studies (Dean and Foran, 1992). The decreased concentrations with subsequent drainage events after manure application may have occurred because, in addition to bacterial mortality, the bacteria moved into the soil matrix and sorbed to clay particles. The fecal bacteria did not necessarily die, but they did not move into the lysimeters with subsequent rainfall until saturated conditions occurred. Bacteria sorbed to soil can become resuspended and travel significant distances under saturated conditions (Rahe et al., 1978). Fecal coliform persistence after spring, moreover, may have contributed to the increased concentrations that we observed in leachate during the late summer of 1993 and 1994, before the fall manure application.

Disturbed or plowed soils may dramatically attenuate bacterial concentrations in leachate water (Dean and Foran, 1992; Smith et al., 1985), so it was interesting that average fecal coliform concentrations in leachate from plowed plots tended to be as high or higher than those from no-tillage plots. The tillage operations, which were a form of conservation tillage, may have insufficiently disrupted soil structure. On the other hand, Qui- 
senberry and Phillips (1976) observed that macropore flow is still possible in tilled soil at the lower boundary of the Ap horizon when the soil is not saturated.

Manure crusting in the no-tillage plots may also have prevented interaction of bacteria with rain. Dried manure deposits exhibit hydrophobic properties (Edwards et al., 1993; Thelin and Gifford, 1983). In addition to providing protective cover, the crusted manure we observed on the no-tillage plots may have prevented water from moving through the deposits, thus lowering leachate concentrations compared to conservation tillage plots.

\section{CONCLUSIONS}

There can be immediate, negative effects of dairy manure application on the bacterial quality of vadose zone water. Substantial fecal coliform movement beyond the root zone occurred whenever there was a rain of sufficient duration or intensity to cause flow, and substantial fecal contamination of leachate occurred regardless of whether manure was fall or spring applied. The seriousness of fecal bacteria movement depends on the proximity of wells and springs to manure application sites, and the dilution of fecal bacteria that occurs in vadose zone water. These were issues that this study could not address. Fecal coliform concentrations, as an indicator of potentially serious bacterial pathogens, usually declined below detectable levels within $60 \mathrm{~d}$ of manure application, which corresponded to the time needed for the fecal coliforms to die-off at the soil surface.

In this study, tillage had no consistent affect on the concentration of fecal coliforms in leachate. The lack of significant differences probably occurred because the tillage performed in conservation tillage plots was insufficient to cause substantial changes in soil structure, moisture, and infiltration. Spring manure was usually a statistically significant factor in many responses, but the manure $x$ tillage interaction was not. Therefore, the agronomic benefits (increased yields) and environmental problems (increased fecal bacteria in leachate) associated with spring manure application applied equally to both tillage systems used in this experiment.

\section{ACKNOWLEDGMENTS}

The technical assistance of Abigail Villalba in microbial analysis and Charles Stangle in data collection is greatly appreciated. This research was supported by agreement (no. 9234214-7360) with the USDA CSRS Special Research GrantsWater Quality program and is published with permission of the director of the Kentucky Agricultural Experiment Station as report no. 97-06-09.

\section{REFERENCES}

Alexander, M. 1982. Most probable number method for microbial populations. p. 815-820. In A.L. Page et al. (ed.) Methods of soil analysis. Part 2. 2nd ed. Agron. Monogr. 9. SSSA, Madison, WI. American Public Health Association. 1992. Standard methods for the examination of water and waste water. 18th ed. APHA, Washington, DC.

Blevins, R.L., W.W. Frye, P.L. Baldwin, and S.D. Robertson. 1990. Tillage effects on sediment and soluble nutrient losses from a Maury silt loam soil. J. Environ. Qual. 19:683-686.

Blevins, R.L., M.S. Smith, G.W. Thomas, and W.W. Frye. 1983. Influence of conservation tillage on soil properties. J. Soil Water Conserv. 38:301-305.

Carmer, S.G., and W.M. Walker. 1988. Significance from a statistician's viewpoint. J. Prod. Agric. 1:27-33.

Corapcioglu, M.Y., and A. Haridas. 1985. Microbial transport in soils and groundwater: A numerical model. Adv. Water Resour. 8: 188-200.

Crane, S.R., P.W. Westerman, and M.R. Overcash. 1980. Die-off of fecal indicator organisms following land application of poultry manure. J. Environ. Qual. 9:531-537.

Davies, C.M., J.A.H. Long, M. Donald, and N.J. Ashbolt. 1995. Survival of fecal microorganisms in marine and freshwater sediment. Appl. Environ. Microbiol. 61:1888-1896.

Dean, D.M., and M.E. Foran. 1992. The effect of farm liquid waste application on tile drainage. J. Soil Water Conserv. 47:368-369.

Edwards, W.W., M.J. Shipitalo, L.B. Owens, and W.A. Dick. 1993. Water and nitrate movement in earthworm burrows within longterm no-till cornfields. J. Soil Water Conserv. 44:240-243.

Elliot, L.F., and J.R. Ellis. 1977. Bacterial and viral pathogens associated with land application of organic wastes. J. Environ. Qual. 6:245-251.

Fontes, D.E., A. L. Mills, G.M. Hornberger, and J.A. Herman. 1991. Physical and chemical factors influencing transport of microorganisms through porous media. Appl. Environ. Microbiol. 57: 2473-2481.

Gannon, J.T., V.B. Manilal, and M. Alexander. 1991a. Relationship between cell surface properties and transport of bacteria through soil. Appl. Environ. Microbiol. 57:190-193.

Gannon, J.T., U. Mingelgrin, M. Alexander, and R.J. Wagenet. 1991b. Bacterial transport through homogenous soil. Soil Biol. Biochem. 23:1155-1160.

Howell, J.M., M.S. Coyne, and P.L. Cornelius. 1996. Effect of particle size and temperature on fecal bacteria mortality rates and the fecal coliform/fecal streptococci ratio. J. Environ. Qual. 25:1216-1220.

Kibbey, H.J., C. Hagedorn, and E.L. McCoy. 1978. Use of fecal streptococci as indicators of pollution in soil. Appl. Environ. Microbiol. 35:711-717.

Peterson, T.C., and R.C. Ward. 1989. Development of a bacterial transport model for coarse soils. Water Resour. Bull. 25:349-357.

Quisenberry, V.L., and R.E. Phillips. 1976. Percolation of surfaceapplied water in the field. Soil Sci. Soc. Am. J, 40:484-489.

Rahe, T.M., C. Hagedorn, E.L. McCoy, and G.F. Kling. 1978. Transport of antibiotic-resistant Escherichia coli through western Oregon hillslope soils under conditions of saturated flow. J. Environ. Qual. 7:487-494.

Reddy, K.R., R. Khaleel, and M.R. Overcash. 1981. Behavior and transport of microbial pathogens and indicator organisms in soil treated with organic wastes. J. Environ. Qual. 10:255-266.

SAS Institute. 1989. SAS user's guide: Statistics. Version 6. SAS Inst., Cary, NC.

Sharma, P.K., and M.J. McInerney. 1994. Effect of grain size on bacterial penetration, reproduction, and metabolic activity in porous glass bead chambers. Appl. Environ. Microbiol. 60:1481-1486.

Smith, M.S., G.W. Thomas, R.E. White, and D. Ritonga. 1985. Transport of Escherichia coli through intact and disturbed soil columns. J. Environ. Qual. 14:87-91.

Thelin, R., and G.F. Gifford. 1983. Fecal coliform release pattern from fecal material of cattle. J. Environ. Qual. 12:57-63.

Thomas, G.W., and R.E. Phillips. 1979. Consequences of water movement in macropores. J. Environ. Qual. 8:149-152.

Turco, R.F. 1994. Coliform bacteria. p. 145-158. In R.W. Weaver et al. (ed.) Methods of soil analysis. Part 2. SSSA Book Ser. 5. SSSA, Madison, WI.

Tyler, D.D., and G.W. Thomas. 1977. Lysimeter measurements of nitrate and chloride loss from soil under conventional and notillage corn. J. Environ. Qual. 6:63-66. 